\title{
Self-psychological and Zakat Institution Factors: It is Reliable to Influence Intention to Pay Zakat among Muslim
}

\author{
Aflah Isa, Nurul Fatehah Mohd Azam, Fairuz Husna Mohd Yusof, Nur \\ Farhana Mohd Daud
}

To Link this Article: http://dx.doi.org/10.6007/IJARBSS/v12-i1/10807

DOI:10.6007/IJARBSS/v12-i1/10807

Received: 19 November 2021, Revised: 24 December 2021, Accepted: 10 January 2022

Published Online: 27 January 2022

In-Text Citation: (Isa et al., 2022)

To Cite this Article: Isa, A., Azam, N. F. M., Yusof, F. H. M., \& Daud, N. F. M. (2022). Self-psychological and Zakat Institution Factors: It is Reliable to Influence Intention to Pay Zakat among Muslim. International Journal of Academic Research in Business and Social Sciences, 12(1), 1892-1903.

Copyright: (C) 2022 The Author(s)

Published by Human Resource Management Academic Research Society (www.hrmars.com)

This article is published under the Creative Commons Attribution (CC BY 4.0) license. Anyone may reproduce, distribute, translate and create derivative works of this article (for both commercial and non0-commercial purposes), subject to full attribution to the original publication and authors. The full terms of this license may be seen at: http://creativecommons.org/licences/by/4.0/legalcode

Vol. 12, No. 1, 2022, Pg. 1892- 1903

Full Terms \& Conditions of access and use can be found at http://hrmars.com/index.php/pages/detail/publication-ethics 


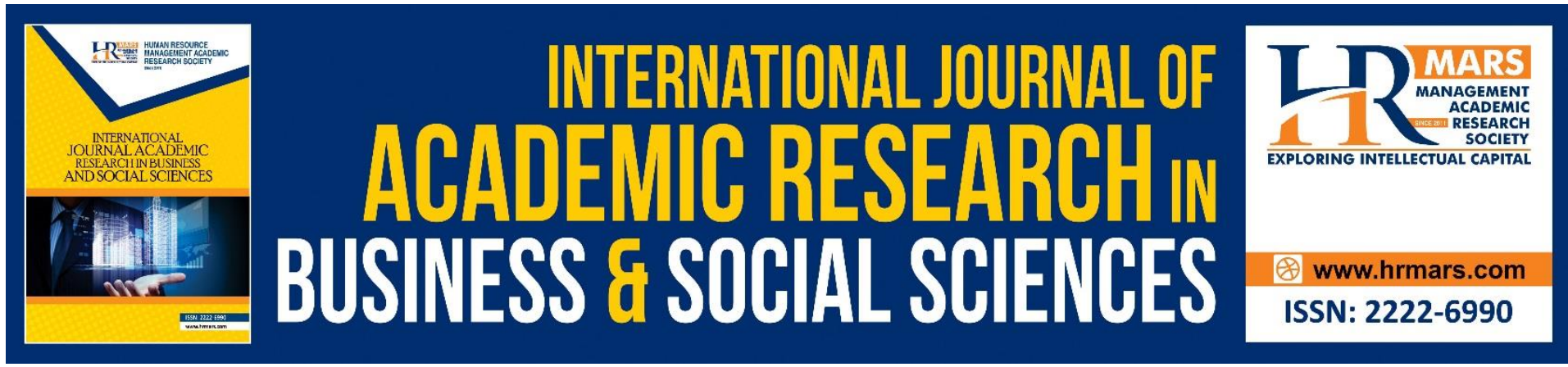

\title{
Self-psychological and Zakat Institution Factors: It is Reliable to Influence Intention to Pay Zakat among Muslim
}

\author{
Aflah Isa ${ }^{1}$, Nurul Fatehah Mohd Azam², Fairuz Husna Mohd \\ Yusof ${ }^{3}$, Nur Farhana Mohd Daud ${ }^{4}$ \\ ${ }^{1,2}$ Faculty of Business and Management Universiti Teknologi Mara, ${ }^{3}$ Academy of Language \\ Studies Universiti Teknologi Mara, ${ }^{4}$ Academy of Contemporary Islamic Studies Universiti \\ Teknologi Mara. \\ Corresponding Author Email: aflah171@uitm.edu.my
}

\begin{abstract}
Paying zakat has been a practice since a long time ago, even in Prophet Muhammad SAW's era. Zakat is one of pillars in Islam. Nowadays, there are lower collection rate of zakat funds, which will give a bad perception toward Islam significantly. This is because it will increase the percentage of poor people among the Muslim community. Therefore, it is very important to make sure Muslims have a high level of intention to pay zakat. Thus, in this study, the main objective is to determine the levels of intention to pay zakat among Muslims. Besides that, this study also aims to examine the effects of five selected cause factors (i.e. Role Identity, Self-Religiosity, Subjective Norm, Satisfaction and Corporate Reputation) toward the intention to pay zakat among Muslims. All these six variables were treated as a primary data, since all these variables were measured directly from the targeted respondents. In this study, around 200 Muslims who passed the criteria of ability to pay zakat will be the targeted sample. The study focussed on Muslim residents and 200 respondents participated in this study. The findings indicated that, all these five selected independent variables such as role identity, self-religiosity, subjective norm, satisfaction, and corporate reputation will give a positive significant influence towards the intention to pay zakat among Muslims.
\end{abstract}

Keywords: Intention to Pay Zakat, Role Identity, Self-Religiosity, Subjective Norms, Satisfaction and Corporate Reputation

\section{Introduction}

Islam is a way of life that is complete. Zakat implies purification and growth. Paying zakat is about purifying one's riches and getting nearer to Allah. Muslims have the belief that Allah will substitute and boost their wealth when they pay zakat. Furthermore, there are five conditions for Muslims who are liable for paying zakat which are being a Muslim, has liberty in life, his or her saving reaches or exceeds nisab and one person's property which will be affected by zakat must follow the correct haul.

Basically, there are two categories of zakat which are zakat on fitrah and zakat on wealth. Firstly, zakat on fitrah is a zakat payment imposed on Muslims during Ramadhan under 
certain conditions. On the other hand, zakat on wealth can be divided into zakat on employment income, business, savings, crops and agriculture, gold and silver, natural resources and shares. In addition, zakat on business is paid based on the profit received during the year, while zakat on employment income is paid on the basis on the salary received. Nisab is the rate to be achieved for compulsory zakat. Depending on the recent gold price, the value of gold equal to 85 grams is determined. In addition, haul is completion period for a zakat asset. It means that the ownership of the property has reached one year. Basically, haul is used in payment of zakat on business, livestock and storage. An individual who owns the same or more money than the nisab rate, and transfers it on the condition that he is obliged to issue zakat by $2.5 \%$ of the total amount of the property he owns. This is based on the gold zakat rate. This practice is suitable as the use of money as a buying power is equivalent to gold and silver. Zakat institutions have given a lot of initiatives to encourage zakat payers to pay zakat like payment via mobile counter, Internet banking, post office and messaging. However, past studies indicate that the collection of zakat is still unsatisfactory. Thus, this research was carried out to identify the factors influencing the high level of intention to pay zakat among Muslims in Kuala Terengganu. This research will explore the connection between Role Identity, Self-Religiosity, Subjective Norm, Satisfaction and Corporate Reputation.

One of the issues that zakat institutions faces is when the zakat payer refuses to pay zakat to the zakat institutions because they have a negative perception towards zakat institution in managing the allocation of zakat funds. Based on this situation, socio-economy among the Muslims can be worsened since the zakat funds can be treated as one of the resources for the Muslims to boost-up their economy. Besides that, with the lower collection rate of the zakat funds, significantly it will give a bad perception towards Islam itself as it will increase the percentage of poor within the Muslims community itself. Therefore, it is very essential to make sure the Muslims have high level of intention to pay zakat.

There are several factors that can influence the level of Muslims' intention to pay zakat, internal and external factors. However, there is still a lack of studies that combine these factors in one research setting. Then, it is worthwhile to perform the factors that influence the level of intention to pay zakat among Muslims. Thus, this study intends to explore whether the psychological factors among the Muslims and zakat institution factors can be some of the factors that can increase their intention to pay zakat. A self-administered questionnaire survey will be given to 200 Muslims as targeted respondents.

\section{Intention to Pay Zakat}

The researcher focuses on the five chosen factors that can determine the Muslims' intention to pay zakat which are Role Identity, Self-Religiosity, Subjective Norm, Satisfaction and Corporate Reputation. Intention refers to association between an individual's potential capacity to undertake a particular job and the final choice of that person that involves whether or not he or she performs that particular job.

According to Ajzen \& Fishbein (1975), the intention is a person's subjective probability dimension which involves a particular individual to perform specific behaviours. The probability of someone to do a specific behaviour depends on their intention. In line with this, if an individual has a favourable attitude towards a specific behaviour, it is expected that an individual will have a good intention toward performing a stipulated task (Muhammad \& Saad, 2016). In the field of zakat, a lot of studies were conducted on an intention to pay zakat (Muhammad \& Saad, 2016). According Haniffa et al (2014)'s study, 227 respondents of active 
businessmen in one district in Malaysia compliance behaviour is significantly influenced by intention to pay zakat.

\section{Literature Review}

\section{Role Identity toward Intention to Pay Zakat}

Muslims must pay Zakat to fulfil Allah's command and take care of the individuals who are in need. Role identity can be defined in specific circumstances as the meanings that people attach to themselves. With regard to a role identity, it is one of the factors which shows that it affects the intention of a person to do something. Belief in something means to shape role identity of people as well as results of the evaluation of a person on a thing or a product. Zakat in Islam is a mandatory responsibility for those capable of ensuring social security for justice and stability (Mahmood, 2009). In financial and social dimensions, role identification plays a major role (Mahmood, 2009). In addtion, zakat is not just a duty of worship, but a financial obligation and a relationship between individuals and their creators as well as covering human relationship with individuals and the community (Mahmood, 2009).

\section{Self-Religiosity toward Intention to Pay Zakat}

In order to organise and regulate human life in all aspects of daily life according to the AlQuran and As-Sunnah, the religion of Islam is revealed by Allah to the Prophet Muhammad s.a.w. In affecting Muslims to pay zakat, religious is one of the most significant variables. Religiosity can be described as the guidelines to be followed by Muslims in performing their daily activities and judgement on the end outcomes of fulfilling the duty to pay zakat (Bidin, Al \& Saad, 2012). To influence the person's personality to perform a good deed or not, selfreligiosity is very important. If the people feel that it is important to fulfil the command of Allah, it will create their high level of intention to pay zakat.

After that, according to Rahim et al (2014), the worship factor which is religiosity is one of the main motivation and determinants of intention to fulfil a religious duty such as Zakat. The person who has high religiosity will comply to pay zakat rather than the person who is not highly religious. This is because the religious components, elements and dimensions can dictate the affective and cognitive functioning that ultimately impacts the judgement of an individual (Bidin et al., 2012). Previous studies have also shown that religiosity has a positive influence on life satisfaction (Willem, 2017). Though religiosity is recognised as a crucial factor in understanding human behaviour, the measurement of religiosity has been an issue in the literature.

Researchers used numerous measurements to measure religiosity (Abou, 2015). According to Palil et al (2013), the individual approach where they measured religiosity depends on how many times the person attends religious activities, whether that person was brought up religiously at home and self-description as a religious or a non-religious person. In addition, some researchers used both religious affiliation and religious commitment to measure religiosity.

In addition, there are studies investigating the influence of self-religiosity towards Muslim's intention to pay zakat. One of the studies investigated this issue where it was conducted by (Abu Bakar et al., 2010). The researchers emphasised the significance between religiosity and Muslims' intention to pay zakat. Then, the religious practices are capable of protecting individuals from getting into dangerous activities (Krauss \& Hamzah, 2007).

According to research by Idris et al (2012), religiosity significantly influences how people participate with certain behaviours after finding that all religious beliefs are in common to 
serve for the purpose of promoting good behaviours and to prevent bad behaviours. A similar study was conducted by Pope \& Mohdali (2010), they found that there is an important connection between self-religiosity and intention as religious plays an important part in the life of people.

Furthermore, according to Idris et al (2012), a positive significant influence between religiosity on the behavioural intention was found in the research. Thus, the study considers that self-religiosity plays a vital role to motivate Muslims towards the intention to pay zakat. In Islam, a person's intention to pay zakat as a religious obligation depends highly on the strength of the person's belief and commitment to the religious itself.

\section{Subjective Norm toward Intention to Pay Zakat}

Subjective norm is the significant factor that will impact behavioural intention to pay zakat. According to Taufique \& Vaithianathan (2018), subjective norm and behavioural intention has a strong connection with each other. It shows the effective use of subjective norm to form the behavioural intention. A previous study stated that the subjective norm is the opinion of another important person or who believes in them to make a decision (Yadav \& Pathak, 2017). If the individual believes in the people, it can help him to decide whether to approve or avoid the rejection.

Subjective norms refer to one's perceptions or assumptions about other people's expectations about the particular behaviours that one will or will not perform. This dimension is called subjective norms since this perception is very subjective in nature. According to (Bidin \& Shamsudin, 2013), subjective norms have a positive relationship with behavioural intention. Subjective norms are related to the perception of other people towards the perpetrator if he did certain acts. Perception, response or the pressure can either be positive or negative. In order to measure this variable of subjective norm, certain questions related to the reactions of other people will be important whether or not someone is doing a particular activity. Parties are meant to be a parent, husband/wife, friend and teacher (Farah, 2011)

According to Jaffar \& Musa (2013), subjective norm has direct impact to the intention. Therefore, both variables are stated to have beneficial effects on each other. Accordingly, the more pressure from important others to comply, the more the strength of intention towards Zakat.

\section{Satisfaction toward Intention to Pay Zakat}

Satisfaction is the next factor that can affect Muslims' desire to pay zakat. Satisfaction is a marketing term relating to business measurement whether a company meets or exceeds customer's expectation through products and services that offered to customers. Therefore, satisfaction is a feeling of happy or sadness arising from the comparison between the perceptions and expectations of the customers (Mujaini, 2012). In addition, to maintain zakat performance, the satisfaction of zakat distribution must be improved in order to encourage the Muslims to pay zakat through zakat institutions (Ellany \& Lateff, 2011). Based on the previous studies, there are some findings regarding the satisfactions of distribution (Zainal, 2016)

The higher of satisfaction to zakat institutions, the higher of people to pay zakat because they have a positive perception toward zakat institution in managing the distribution of zakat funds. Therefore, it is very important to make sure a Muslims people have a high satisfaction to zakat institution that can influence the level of intention to pay zakat among Muslims. It is expected that a Muslims who has a high level of satisfaction on the zakat 
distribution would contribute to a greater trust in zakat institutions and vice versa. Based on this systematic review, the fourth hypothesis was developed.

\section{Corporate Reputation toward Intention to Pay Zakat}

Other than that, corporate reputation is a factor that can affect the intent to pay zakat. Reputation is the general stakeholders' perception of the company's results from time to time (Richard \& Zhang, 2012). Therefore, it is possible to achieve reputation by information from people around or other sources. Positive information can enhance the trust of customers and can increase their level of intention to pay zakat. According to Abratt and Kleyn (2012), the company's reputation will establish consumers' trust in a company. Therefore, a company's reputation is the ultimate determinant in meeting consumers' expectations and demand of consumers (Abratt \& Kleyn, 2012) and as an evaluation to what extent an organisation is highly regarded by them.

According to the Concise Oxford Dictionary, reputation can be defined as "what generally said or believed about the personality or position of a person or thing". This means that reputation is what publicity or belief in feature or position. Reputation can be linked by groups or individuals. A group can be assessed by outsiders based on the reputation of its members or of the group's overall average (Jøsang et al., 2007).

Therefore, reputation can be achieved through information from around or other sources. This proves that the reputation is the important factor influence the level of intention to pay zakat among Muslims. Thus, the reputation can be used as a measure of intention to pay zakat. In an environment of zakat, positive corporate reputation toward zakat institutions can increase the number of total collections of zakat payers. However, negative corporate reputation cause people to pay zakat. So, the researcher assumes that the positive information of corporate reputation is a factor to build the high level of intention to pay zakat among Muslims.

\section{Methodology}

Primary data was obtained from the study through a distribution of the questionnaires to the respondents that was conducted specifically for this research. A set of structured questionnaires was used in this research. This is because in a short time, targeted information will be gathered from a large number of people. In addition, the researcher used face-to-face and google form technique to respond directly to a questionnaire. Approximately 200 questionnaires were distributed to the targeted respondents in printed hard copies. Questionnaires are formed of six parts. Part A is about respondents' demographic profiles such as age, gender, marital status, education level, occupation and monthly income. Part B is related to the dependent variables which are Intention to Pay Zakat while Part C, Part $D$, Part E, Part F, and Part G related to independent variables which are Role Identity, SelfReligiosity, Subjective Norms, Satisfaction and Corporate Reputation.

\section{Findings}

Respondent Profile

In this section, the background information of respondents participating in this study was presented. The distribution of respondents based on gender indicated that, about $61.4 \%$ of the respondents were female whereas $38.6 \%$ of the respondents were male respondents, thus it is indicated that, female respondents were the majority respondents who participated in this study. 
Furthermore, it also can be concluded that, a majority of the respondents participated in this study were in the range of 41 years old to 50 years old (37.9\%) whereas respondents who were below 21 years old (10.7\%) can be considered as minority groups of age. As for marital, the most of frequency is 92 which is (65.7\%) respondents are married while for minority frequency is 7 which is (5.0\%) respondents that participated in this study are divorced.

Based on the survey, the highest education of respondents in this study mostly was from secondary school level (52.1\%) whereas $0.7 \%$ of the respondents can be considered as minority group from master's degree level. Besides that, for the occupation, a majority of the respondents come from self-employed that get the highest percentage which is $40.0 \%$ whereas the retired is considered as minority group of occupation $(6.4 \%)$ respondents in this study.

For the monthly income, a majority of the respondents come from RM 1000 and below and RM $1001-$ RM 2500 that get the highest percentages (32.9\%). The two groups of monthly income get the same percentages of the respondents that participated. Then, the respondents who are having a monthly income between RM 2501 - RM 4000 (26.4\%) can be considered as the three highest groups of the monthly income among them whereas RM 5501 and above that get the lowest percentages $(2.9 \%)$ can be considered as minority groups of monthly income.

\section{Reliability Assessments}

Table 1 Summary results of Cronbach's Alpha

\begin{tabular}{|l|l|l|}
\hline $\begin{array}{l}\text { Factors and Items } \\
\text { Included }\end{array}$ & Factor Loading & Communalities \\
\hline Role Identity & Eigenvalue $=10.890, \%$ variance explained $=36.752 \%$, Cronbach's alpha $=.914$ \\
\hline Self-Religiosity & Eigenvalue $=8.444, \%$ variance explained $=67.937 \%$, Cronbach's alpha $=.944$ \\
\hline Subjective Norms & Eigenvalue $=4.580, \%$ variance explained $=80.092 \%$, Cronbach's alpha $=.961$ \\
\hline Satisfaction & Eigenvalue $=3.449, \%$ variance explained $=91.550 \%$, Cronbach's alpha $=.935$ \\
\hline Corporate Reputation \\
\hline Eigenvalue $=2.543, \%$ variance explained $=93.348 \%$, Cronbach's alpha $=.909$ \\
\hline Intention to Pay Zakat \\
\hline Eigenvalue $=1.358, \%$ variance explained $=94.740 \%$, Cronbach's alpha $=.982$ \\
\hline
\end{tabular}

The result from table 1 showed that, all the 33 items exceeded the value of factor loading which is .50 (Range: .747 to .946). Subjective Norms (Cronbach's Alpha = .961), Self- Religiosity (.944), Satifaction (Cronbach's alpha $=.935)$, Role Identity (Cronbach"s alpha $=.914$ ) and Corporate Reputation (Cronbach's alpha $=.909$ ). Dependent variable which is Intention to Pay 
Zakat (Cronbach's Alpha $=.982$ ). It shows the strength of questionnaire to one other which is acceptable level of reliability values.

\section{Correlation Analysis}

Table 2: The Correlation analysis variables under investigation

\begin{tabular}{|l|l|l|l|l|l|l|}
\hline & $\mathbf{( 1 )}$ & $\mathbf{( 2 )}$ & $\mathbf{( 3 )}$ & $\mathbf{( 4 )}$ & $\mathbf{( 5 )}$ & $\mathbf{( 6 )}$ \\
\hline $\mathbf{( 1 )}$ & 1.000 & & & & & \\
\hline $\mathbf{( 2 )}$ & $.624^{* *}$ & 1.000 & & & & \\
\hline $\mathbf{( 3 )}$ & $.558^{* *}$ & $.424^{* *}$ & 1.000 & & & \\
\hline $\mathbf{( 4 )}$ & $.612^{* *}$ & $.512^{* *}$ & $.702^{* *}$ & 1.000 & & \\
\hline $\mathbf{( 5 )}$ & $.705^{* *}$ & $.535^{* *}$ & $.712^{* *}$ & $.908^{* *}$ & 1.000 & \\
\hline $\mathbf{( 6 )}$ & $.674^{* *}$ & $.455^{* *}$ & $.785^{* *}$ & $.870^{* *}$ & $.854^{* *}$ & 1.000 \\
\hline
\end{tabular}

Note: (1) = Role Identity; (2) = Self-Religiosity; (3) = Subjective Norms; (4) = Satisfaction; (5) = Corporate Reputation; (6) = Intention to Pay Zakat; $n=140 ; * * p<.01$.

The Pearson's Correlation was used to explore the bivariate relationship of two interested variable because the variable's normality hypothesis met (Pallant, 2010). This analysis can take value from -2.00 to +2.00 ranges. The front sign shows the positive or negative direction of the correlation (Pallant, 2010). In addition, for using this sort of correlation, each variable must usually be distributed, (Pallant, 2010). Since each variable passed the test of normality (i.e. Section 4.6), the results of the analysis of correlation reported in Table 2 were valid and unbiased.

From the result of the correlation analysis reported in Table 2, Role Identity $(r=.674, p<.01)$, Self-Religiosity $(r=.455, p<.01)$, Subjective Norms $(r=.785, p<.01)$, Satisfaction $(r=.870, p$ $<.01)$, Corporate Reputation $(r=.854, p<.01$ ) were positively bivariate correlated toward Intention to Pay Zakat. In addition, these correlation strengths can be assumed to have a moderate correlation relationship. In addition, the bivariate relationship among the targeted variables in this study were positive relationship with a highly significant relationship $(p<.01)$.

\section{Multiple Linear Regression Analysis}

Table 3 Summary results of regression analysis of independent variables to dependent variable

\begin{tabular}{|l|l|l|l|l|l|}
\hline $\begin{array}{l}\text { Independent } \\
\text { Variables }\end{array}$ & B (SE) & beta & t-statistic & P-value & TOL, VIF \\
\hline Role Identity & $.167(.048)$ & .187 & 3.448 & $.001^{* *}$ & $.404,2.478$ \\
\hline Self-Religiosity & $.112(.049)$ & .113 & 2.286 & $.024^{*}$ & $.583,1.715$ \\
\hline Subjective Norms & $.294(.051)$ & .291 & 5.772 & $.000^{* *}$ & $.467,2.140$ \\
\hline Satisfaction & $.443(.077)$ & .489 & 5.743 & $.000^{* *}$ & $.164,6.092$ \\
\hline $\begin{array}{l}\text { Corporate } \\
\text { Reputation }\end{array}$ & $.106(.051)$ & .096 & 2.096 & $.047^{*}$ & $.136,7.377$ \\
\hline
\end{tabular}


Note: Dependent Variable $=$ Intention to Pay Zakat; $R^{2}$ adjusted $=.835$, Standard Error of Estimate $=.30659 ;$ Model Fits $=F(5,134)=141.288, \mathrm{p}<.001 ; \mathrm{B}=$ Unstandardized Coefficients; beta $=$ Standardized Coefficient; SE = Standard Error; TOL = Tolerance; VIF = Variance Inflation Factor; ${ }^{*} p<.05 ;{ }^{* *} p<.01$.

A multiple regression analysis was performed between a set of targeted independent variables (i.e. Role Identity, Self-Religiosity, Subjective Norms, Satisfaction, Corporate Reputation) toward Intention to Pay Zakat. The analysis reported in Table 3 indicated that, Role Identity $(B=.167, p<.01)$, Self- Religiosity $(B=.112, p<.05)$, Subjective Norms $(B=$ $.294, p<.01)$, Satisfaction $(B=.443, p<.01)$ and Corporate Reputation $(B=.106, p<.05)$ had positive significant influence toward Intention to Pay Zakat. It means that all the null hypotheses for the five independent variables are rejected.

The analysis indicated that, if the average level of Role Identity was high, then the average level of intention to pay Zakat was also high, while controlling other factors to be constant. The same conclusion can be concluded for the effect of self-religiosity, subjective norms, satisfaction and corporate reputation toward intention to pay Zakat. Therefore, if the average level of self-religiosity, or subjective norms, or satisfaction, or corporate reputation was high, then the average level of intention to pay Zakat will also be high, by controlling other variables respectively.

On the other hand, the regression model above shows that, Satisfaction (beta $=0.489$ ) gave the highest influence towards intention to pay Zakat since it has a highest value of standardised coefficient regression (i.e. beta). subjective norms (beta $=0.291$ ) was found as giving a second highest influences toward intention to pay Zakat, followed by role identity (beta $=0.187$ ). After that, Self-Religiosity (beta $=0.113$ ) and lastly corporate reputation (beta $=0.096)$. In addition, these set of independent variables were able to explain about $R^{2}$ adjusted $=0.835$ variance towards intention to Pay Zakat.

\section{Conclusion}

The aim of the study was to assess the factors that influence intention to pay Zakat among Muslims in Kuala Terengganu. In this research, the independent variables are Role Identity, Self-Religiosity, Subjective Norms, Satisfaction and Corporate Reputation while the dependent variable is Intention to Pay Zakat. 200 questionnaires were distributed to the Muslim residents in Kuala Terengganu but only 140 respondents submitted usable questionnaire. In addition, the data was analysed by using the Statistical Package for the Social Science (SPSS) software.

Based on the finding, multiple regression analysis was performed between a set of targeted independent variables (i.e. Role Identity, Self-Religiosity, Subjective Norms, Satisfaction and Corporate Reputation) toward the Intention to Pay Zakat, and the regression model also met the minimum requirement of the model validity. The regression analysis indicated that Role Identity, Self-Religiosity, Subjective Norms, Satisfaction and Corporate Reputation had positively significant influences toward Intention to Pay Zakat.

\section{Recommendations}

\section{Recommendation for the Zakat Company}

Since the findings of this study established a statistically significant relationship between independent variables (i.e. Role Identity, Self-Religiosity, Subjective Norms, Satisfaction and Corporate Reputation) toward dependent variable (i.e. Intention to Pay Zakat). It is 
recommended that some actions to be taken by the Zakat Company based on the analysis findings, to attract the intention to pay Zakat among Muslims. Firstly, Zakat Company need to organise the strategy to enhance the collection of zakat in every year. This strategy may include doing some activities such as giving talk, campaign and workshop including students, private and public workers, businessman and all Muslim who are eligible to pay zakat. With this activity, the level of awareness of the importance of paying zakat can be increased among the Muslim community. Furthermore, according to the finding in this study, the Subjective Norm also has effects toward intention to pay Zakat. The surrounding people play a very important role that can influence respondents to have an intention to pay zakat. Therefore, Zakat company has to give good services, so that it will attract more people to have the intention to pay zakat.

\section{Recommendation for the Future Researcher}

In this study, the factors that can influence to the intention to pay zakat among Muslims are Role Identity, Self-Religiosity, Subjective Norms, Satisfaction and Corporate Reputation. However, these are not only factors that influence the intention to pay zakat. The researcher can find other factors such as Behavioural Beliefs, Attitudes and Willingness to pay. Thus, based on the above recommendations, future researchers may have more options and guideline to carry out this topic to have a better finding in the future research.

\section{Summary}

In a nutshell, all the five independent variables which are Role Identity, Self-Religiosity, Subjective Norms, Satisfaction and Corporate Reputation have significant relationship to Intention to Pay Zakat which is the dependent variable of this study. Other than that, the researchers also include the conclusion and recommendations that can be used for the future researcher as a guideline.

\section{References}

Abu Bakar, N. B., Abdul Rashid, H. M., \& Rashid. (2010). Motivations of Paying

Zakat on Income : Evidence from Malaysia. International Journal of Economics and Finance, 2(3), 76-85. Retrieved from http://ccsenet.org/journal/index.php/ijef/article/view/6087

Ajzen, I., \& Fishbein, M. (1975). Belief, attitude, attitude, intention and behavior: An introduction to theory of research. Reading, MA : Addison-Wesley AddisonWesley.

Bidin, Z., Al, R., \& Saad, J. (2012). Islamic Religiosity Measurement and Its Relationship with Business Income Zakat Compliance Behavior, 34, 3-10.

Bidin, Z., \& Shamsudin, F. M. (2013). Using Theory of Reasoned Action to Explain Taxpayer Intention to Comply with Goods and Services Tax ( GST ) School of Accounting, College of Business, Othman Yeop Abdullah Graduate School of Business , 17(3), 387-394. https://doi.org/10.5829/idosi.mejsr.2013.17.03.12167

Creswell, J. W. (2012). Educational Research: Planning, Conducting, and Evaluating Quantitative and Qualitative Research. Boston, MA:Pearson.

Ellany, E., \& Lateff, A. (2011). Faktor-Faktor Yang Mempengaruhi Pembayaran

Zakat Pendapatan Di Malaysia Factors Influencing Income Zakat Payment in Malaysia, 1, 148-159.

Farah, M. (2011). Zakat Compliance Intention Behavior On Saving Among Universiti Utara Malaysia"s Staff. 
Field, A. (2009). Discovering Statistics Using SPSS, 3rd Edition. London:SAGE Publications.

Haniffa, R., \& Saad, A. J. R. (2014). Determinants of zakah (Islamic tax) compliance behavior. Journal of Islamic Accounting and Business Research, 5(2), 182-193.

Idris, K. M., Bidin, Z., \& Saad, R. A. J. (2012). Islamic religiosity measurement and its relationship with business income zakat compliance behavior. Jurnal Pengurusan.

Jaffar, M. A., \& Musa, R. (2013). Determinants of Attitude Towards Islamic Financing Among Halal-Certified Micro and SMEs: A Proposed Conceptual Framework. International Journal of Education and Research. https://doi.org/10.2139/ssrn.2540610

Jøsang, A., Ismail, R., \& Boyd, C. (2007). A survey of trust and reputation systems for online service provision. Decision Support Systems. https://doi.org/10.1016/j.dss.2005.05.019

Krauss, S. E., \& Hamzah, A. (2007). Adaptation Of A Muslim Religiosity Scale For Use With Four Different Faith Communities In Malaysia. Review Of Religious Research.

Mahmood, A. M. (2009). Tuntutan agama dalam membuat perancangan harta. Perancangan Harta Individu Dan Harta Syarikat Islam, 1-30.

Muhammad, S. A., \& Saad, R. A.-J. (2016). Moderating Effect of Attitude toward Zakat Payment on the Relationship between Moral Reasoning and Intention to Pay Zakat. Procedia - Social and Behavioral Sciences, 219, 520-527. https://doi.org/10.1016/j.sbspro.2016.05.029

Mujaini, T. (2012). Zakat al-mal al-mustafad : amalan dan pengalaman di Malaysia. Pusat Pungutan Zakat, Kuala Lumpur.

Palil, M. R., Akir, M. R. M., \& Ahmad, W. F. W. (2013). The perception of tax payers on tax knowledge and tax education with level of tax compliance: A study the influences of religiosity. ASEAN Journal of Economics, Management and Accounting, 1(1), 118-129.

Pope, J., \& Mohdali, R. (2010). The role of religiosity in tax morale and tax compliance. Australian Tax Forum.

Rahim, M., Mohd, R., Salleh, A., \& Nawi, A. S. (2014). Do Religious Practices Influence Compliance Behaviour of Business Zakat among SMEs? Journal of Emerging Economies and Islamic Research.

Richard, J. E., \& Zhang, A. (2012). Corporate image, loyalty, and commitment in the consumer travel industry. Journal of Marketing Management, 28(5-6), 568-593. https://doi.org/10.1080/0267257X.2010.549195

Sekaran, U., \& Bougie, R. (2010). Research method for business: A skill building approach, 5th edition. United States: John Wiley \& Sons Inc.

Sekaran U. (2003). (2003). Research Methods for Business; Skills Building Approach, 4th edition, John Wiley and sons, New York. Journal of MultiDisciplinary Evaluation.

Taufique, K. R., \& Vaithianathan, S. (2018). A Fresh Look at Understanding Green Consumer Behavior among Young. Journal of Cleaner Production. https://doi.org/10.1016/j.jclepro.2018.02.097

Willem, K. (2017). The Effect of Religiosity on Life Satisfaction in a Secularized

Context : Assessing the Relevance of Believing and Belonging. Review of Religious Research, 59(2), 135-155. https://doi.org/10.1007/s13644-016-0282-1

Yadav, R., \& Pathak, G. (2017). Determinants of Consumers' Green Purchase Behavior in a Developing Nation: Applying and Extending the Theory of Planned

Behavior. Ecological Economics (Vol.

134).

https://doi.org/10.1016/j.ecolecon.2016.12.019 
Youssef Abou, H. M. M. (2015). Effects of religiosity on consumer attitudes toward Islamic banking in Egypt". International Journal of Bank Marketing, 33(6), 786-807. Zainal, H. (2016). The Role of Reputation, Satisfactions of Zakat Distribution, And Service Quality in Developing Stakeholder Trust In Zakat Institutions, 524-530. https://doi.org/10.15405/epsbs.2016.08.74 